\title{
Study on the Development Potential of Cruise Ship Tourism in Tianjin
}

\author{
Li Xiaonan \\ Hospitality department \\ Tianjin maritime college, TMC \\ Tianjin,China \\ E-mail:1ily2019151412@163.com
}

\begin{abstract}
Cruise ship tourism has great potential and bright prospects in China. As one of the cruise ship tourism development experimental zones in China, Tianjin has a unique advantage and huge development potential to develop cruise ship tourism. This paper focuses on the development potential in Tianjin based on the foundation of its current situation, and aims at studying the solution on the development of cruise ship tourism in Tianjin,taking its unique advantages into consideration.
\end{abstract}

Keywords-Tianjin;cruise tourism;development;poten-tial;study

ship

\section{INTRODUCTION}

Cruise ship tourism is a kind of high-end tourism activity, with large luxury cruise ships as its carrier, sea cruising as its main form, and onboard activities and onshore leisure tourism activities as its main contents[1]. In North America, Europe and other developed countries, cruise ship tourism is widely welcomed and has become an important way of taking holiday. Although China started relatively late, but with the development of outbound tourism market, especially the transformation and upgrading of the consumption of Chinese tourists, cruise ship tourism has great potential and bright prospects in China. As the economic center of circum-Bohai-Sea region in China, and internationally renowned port city, Tianjin has the unparalleled advantages and great potential on the development of cruise ship tourism, if carefully tapping its characteristics and advantages, nurturing and developing cruise ship tourism market, it can not only bring significant economic benefits, but also greatly promote the link of Tianjin and China's cruise ship tourism with international cruise ship tourism, at the same time it can enhance the image and international status of Tianjin.

\section{THE CURRENT DEVELOPMENT SITUATION OF THE CRUISE SHIP TOURISM IN TIANJIN}

Cruise ship tourism in Tianjin is at its initial stage. In 2010, Tianjin has build Asia's largest cruise home port Tianjin International Cruise Home Port. With a homeport planning area of 1.6 million square meters, a shoreline length of 2,000 meters, it can arrange six large international cruise berths, and accommodate the world's largest luxury cruise ship[2]. On June 26, "Costa Romantica", on her maiden voyage at home port of Tianjin, opened the prelude to the rapid development of cruise ship tourism in Tianjin. In 2011, the well-known luxury cruise "Legend of the Seas" from American Royal Caribbean cruises Ltd, on her maiden voyage at Tianjin
International Cruise Home Port, helped to boost cruise industry in Beijing- Tianjin-Hebei region to the high-end development. On April 20, 2013, Malta international luxury cruise "Millennium" from Celebrity Cruises under American Royal Caribbean cruises Ltd, berthed alongside Tianjin International Cruise Home Port, which is the 11st International cruise ship berthed alongside Tianjin Port in 2013, and also the 101st international luxury cruise accommodated by Tianjin International Cruise Home Port since its opening[3]. On October 23, 2015, "Quantum of the Seas" set sail for the first time in the Tianjin International Cruise Home Port, which is so far the largest international cruise at maiden voyage in China's cruise home port, also Asia's largest cruise ship, and currently the cruise with highest scientific and technological content worldwide. Its maiden voyage injected new vitality to the rapid development of the cruise industry of Tianjin. According to statistics, in 2015, Tianjin Port started its first full-year operation, accommodated 96 cruise ships and about 460,000 passengers inbound and outbound in the whole year. In the next year, it is expected to accommodate 150 cruise ships, and 650,000 visitors[4].

\section{AN ANAL YSIS ON THE POTENTIAL OF CRUISE SHIP TOURISM DEVELOPMENT IN TIANJIN}

\section{A. huge tourist market, and cruise tourism demand}

Studies have shown that there is demand for cruise tourism when per capita GDP reached \$ 6000-8000. Per capita GDP in Tianjin is more than 9000 dollars. Beijing and Tianjin have more than 28 million resident people[5]. As the center of circum-Bohai-sea region, and the "sea gateway" in northern China, Tianjin will be backed by a huge tourist market from more than a dozen of inland provinces in northern China during its development of cruise ship tourism. Especially in the short term, in addition to the Beijing-Tianjin region, the development potential of Hebei, Shandong, Liaoning, Jilin and other neighboring tourist markets is huge. Meanwhile, according to data from the National Tourism Bureau, in recent years, Tianjin's foreign tourists continued to maintain high growth. Japan and South Korea are China's largest tourist markets, whose tourists from sea route to northern China in recent years has remained stable, and the potential number of visitors cannot be underestimate

\section{B. Rich tourism resources and convenient transportation}

In recent years, Tianjin is increasing efforts to develop tourism resources, especially tourism resources relying on 
marine. We have launched a number of high-grade marine tourism products. Meanwhile, Tianjin is backed by Beijing, Tianjin, Hebei, Shanxi, Shaanxi and other places bound for tourism resources and human resources, which means that it is surrounded by many world-class tourist attractions, for example, above $2554 \mathrm{~A}$ level scenic spots, 7 World Heritages, and many kinds of tourism resources with large density and high level. With the opening of the Beijing-Tianjin intercity railway, "half-hour metropolitan area" in Beijing-Tianjin region is formed. Threedimensional traffic gives Tianjin International Cruise Home Port convenient transportation, and makes it an ease of access for international cruise ships and tourists to Beijing, Tianjin and circum-Bohai -sea city group. Forming a pattern of "Integrated tourism in BeijingTianjin-Hebei region" will attract more international tourists to stay and consume in the port city and its surrounding areas.

\section{The Tianjin International Cruise Home Port was completed and put into use}

In 2010, Asia's largest cruise home port - Tianjin International Cruise Home Port was completed and put into use in the Dongjiang Bonded Port Area, to meet the needs of a variety of international cruise ships including the world's largest cruise ship. More than five years since its opening, Tianjin International Cruise Home Port, as the first cruise homeport in northern China, show its absorption gradually. Binhai New Area plays an active role for growth of Chinese cruise market. It is expected that in the next 5 to 10 years, it will usher in many of the world's super-luxury cruise ships and a 6-to-7- time growth in tourists[6].

To push Tianjin International Cruise Home Port to the world, Tianjin Municipal Tourism Bureau participates in world-class tourism promotion conferences every year, such as the Miami cruise fair, ITB in Berlin, the International Tourism Fair in Osaka, Japan and many other important tourism conferences.

Chinese cruise industry's annual event - China Cruise Industry International Cruise Conference and Expo for two consecutive years in the Tianjin Binhai New Area held a strong impetus to the vigorous development of Tianjin cruise tourism.

The Tianjin Binhai New Area was officially established as the Chinese cruise ship tourism Development Experimental Zone

On April 4, 2013, the National Tourism Administration formally approved the establishment of Chinese cruise tourism Development Experimental Zone in Tianjin Binhai New Area[7], which brings the Tianjin international cruise ship tourism into national development strategies. National Tourism Administration pointed out that Binhai New Area, as Chinese cruise ship tourism development experimental zone, should promote the cruise industry policy system, homeport construction management capabilities, the cruise industry service quality, training local cruise service force, and the cruise economy industry level, etc. It should also strengthen research in key areas, explore experiment, actively cooperate with other cruise ship tourism cities, continue to accumulate experience and play a full demonstration function and leading role for the sustained, rapid and healthy development of cruise ship tourism in our country. This marks the Tianjin international cruise ship tourism industry stepping into the new stage of innovative, leading, and integrated development.

Take the lead in the development of cruise-related education and training

At present, there are two colleges-Tianjin Normal University and Tianjin Maritime College opening cruise ship tourism major in Tianjin. In 2006, Tianjin Maritime College took the lead to declare cruise service major in the national vocational college, and opened enrollment in 2007, in recent years Tianjin Maritime College has transported a large number of talents for the cruise industry. In order to further meet the international cruise market's needs for the cruise talents, and promote the cooperation between cruise talent training colleges in China, on November 8,2012,under the support of China Cruise \& Yacht Industry Association, Tianjin Maritime College led and banded more than ten cruise talent training undergraduate universities and specialty institutes together to set up China Alliance of Cruise Talent Education and Training, referred CACTET, with the expectation to achieve the common development in enrollment, training, internship and employment. At the inaugural meeting of CAACTET, Royal Caribbean Cruises Ltd. of America and Tianjin Maritime College signed a memo to build RCCL cruise talent training center together, on April 11, 2013, new employee orientation and pre-service training of RCCL was officially in Tianjin Maritime College, which marked the start of cooperation to build a world-class cruise training base project.

\section{THE CONSTRAINTS OF TIANJIN CRUISE SHIP TOURISM DEVELOPMENT}

Lack of government support policies on the development of cruise

\section{A. ship tourism.}

Cruise ship tourism is a new industry in our country, so how to develop cruise ship tourism is still in the exploration and experimentation stage, at this stage, national support policies and regulations on the development of cruise ship tourism is not perfect. As cruise Development Experimental Zone, Tianjin has not yet issued the relevant planning and support policies on cruise ship tourism development.

\section{B. Public awareness of cruise ship tourism is low}

Cruise ship tourism started relatively late in China, plus with low publicity, the public awareness of cruise ship tourism is generally low. In addition, compared with the traditional tourism products, the destination of cruise ship tourism product is the cruise ship itself, while in the traditional concept of consumption of Chinese tourists, the cruise is only a means of transportation, thus, people don't have good cruise ship consumption attitudes. These factors will restrict the development of Tianjin cruise ship tourism to some extent.

\section{The available cruise routes for Chinese tourists are too little}

In Tianjin, for example, Tianjin International Cruise Home Port as a cruise homeport, most routes are designed for Japan and South Korea and other countries, with few 
cruise routes varieties, and a small range of options. So there is no way to get visitors to buy the cruise products, which limits the fast development of cruise ship tourism.

\section{SOLUTIONS ON TIANJIN CRUISE SHIP TOURISM DEVELOPMENT}

\section{A. Strengthen publicity efforts to Tianjin cruise ship tourism}

Chinese cruise market has great potential, but residents have less understanding of cruise ship tourism, which requires a variety of promotional tools for residents to understand cruise ships and cruise ship tourism, while leading their travel ideas and changing their consumption patterns - from pure touring to leisure vacation. Tianjin cruise tourism promotion should be focus on two aspects. First, actively introduce development of Tianjin cruise ship tourism to local and domestic residents, and guide them to participate in the cruise ship tourism; Second, introduce the advantages of Tianjin to the international cruise companies and visitors around the world, to attract international cruise companies to invest, and more tourists to visit.

\section{B. Establish the image of Tianjin as a cruise ship tourism city.}

Image of a city is its character, demonstrating its unique features to others. The special image of a city that widely recognized by everyone, often become the focus of the world that leads cultural trend of the world. Tianjin has developed China's largest cruise home port up to now, and its Binhai New Area was officially established as the China national cruise ship tourism Development Experimental Zone, which helps to promote the image of Tianjin as a cruise ship tourism city. Tianjin should make good use of the golden opportunity of China's cruise ship tourism development to refine Tianjin's tourism image, and shape its brand of "Cruise City" worldwide[8].

\section{Government policy support for the development of cruise ship tourism}

Cruise ship tourism development requires a wide range of policy support. At present, in order to attract international cruise companies, cruise ships and cruise business, the Binhai New Area has launched a number of policies relating to affiliated shipping fees for international cruise companies, facilitate customs clearance and other policies. It gives cruise companies certain financial support up to $\$ 1$ million per year according to nature of their establishment in Dongjiang bonded Port Area, the type, numbers and growth capacity of their routes. In addition, the Binhai New Area has given foreign passengers in Tianjin international cruise home port the convenience of transit visa policy, which effectively improves the efficiency of clearance.

\section{Strengthening regional cooperation}

With the completion of the cruise home port of Tianjin, Tianjin has become the cruise ship tourism hub of circumBohai -sea region. On the one hand, we must actively seek cooperation with Dalian and Qingdao, and promote the formation of the North China and circum-Bohai-sea region ports to achieve functional complementation[9], dislocation development, and highlight route advantages to Japan and South Korea route to attract southern cruise ships; On the other hand, we should establish interprovincial cruise ship tourism cooperation and coordination mechanism, and achieve the goal of win-win. Strengthen cooperation and ties with other port city groups, such as signing a memorandum of cooperation, to share common resources of tourism and tourists.

\section{To cultivate high-quality cruise tourism professionals}

At present, Tianjin, Dalian, Hainan and other places, are actively preparing for building local cruise companies. At that time, the shortage of cruise ship tourism services and management talents will become a major obstacle to the healthy operation of our local cruise companies. Professionals with high quality and strong ability in the cruise industry are almost the core of the cruise industry. Tianjin ranks first in the domestic cruise ship tourism personnel training, and we should continue to start from the personnel training mode, establish multi-channel mode by integrating schools, government, industry, academia and research closely. We should cooperate with the cruise yacht club of China Communications and Transportation Association and other departments to cultivate world-class management talents with an international perspective and good knowledge about the rules of international cruise management services.

\section{CONCLUSION}

Chinese cruise market has great potential. The World Tourism Organization predicts that by 2020 China will rank first in tourist destination worldwide, and became the fourth source country of tourists. Under the background of a rapid growth of the tourism industry, China has a increasingly better timing of develop cruise ship tourism.

As China's cruise tourism development experimental zone, Tianjin's on its golden time of develop cruise ship tourism.

We should take the opportunity of the completion and operation of Tianjin International Cruise Home Port, tap its unique advantages and get over its obstacles and make for its insufficient, to cultivate its market potential to the greatest extent and establish its image of worldwiderenowned "Cruise City".

\section{REFERENCES}

[1] Gibson, Philip.Cruise operations management[M].London:Routl-

[2] edge,2012.

[3] http://www.tichp.com/

[4] http://www.tichp.com/

[5] http://www.tichp.com/

[6] Beijing, Tianjin and Hebei province are still in the demographic dividend period[N].Hebei Youth Daily, July 10, 2015 A02 version.

[7] Jiang Song. Research on the development of economy of cruise ship tourism in Tianjin Binhai New Area [J]. Journal of Tianjin Vocational Institute,2010,19(6):6-9.

[8] http://www.cnta.gov.cn/

[9] Wang Qingsheng, Liuwen Lei, Yang Qian. Tianjin cruise tourism development [J]. Economic Research Guide, 2011 (3):169-170.

[10] Shen Lihua, Yang Xiaofei, Dongjiang Chun. Study on the potential of Qingdao development of cruise tourism economy [J]. Consumer Economics, 2012,28 (1):65-68. 